\title{
РЕЗУЛЬТАТЫ АРХЕОЛОГИЧЕСКОЙ РАЗВЕДКИ ДРЕВНИХ ПАМЯТНИКОВ В ГОРАХ ХАНТАУ, АЙТАУ И КИНДЫКТАС
}

\author{
(C) 2020 г. А. А. Горячев, С. А. Потапов, Р. В. Ильин
}

В статье систематизированы результаты исследований древних памятников в горах Хантау, Айтау, Кулжабасы и Киндыктас. Поскольку предварительные сведения показывали плотную насыщенность региона древними памятниками, первым этапом практических исследований стала их разведка по космическим снимкам с последующим натурным обследованием. Камеральная обработка и систематизация полученных материалов проводилась с целью выяснения хозяйственно-культурных традиций населения региона в эпоху палеометалла. Площадь территория обследования составила около 4000 кв. км. Собран материал по топографии около 500 памятников эпохи палеометалла и раннего железного века, а также планиграфии более 200 из них. Обследовано свыше 20 поселений, 165 могильников и 17 скоплений петроглифов древних периодов. Выявлено пять горных выработок эпохи палеометалла Киндыктаского горно-металлургического центра. Результатом разведки стали данные для определения конкретных маршрутов древних миграций в западной части Хантауского транзитного коридора.

Ключевые слова: археология, Жетысу, Центральный Казахстан, транзитный коридор, эпоха палеометалла, археологическая карта, поселение, могильник, петроглифы, горные выработки, археологический комплекс

\section{Введение}

В полевом сезоне 2019 г. было проведено обследование горной цепочки Хантау-Айтау-Киндыктас с целью обнаружения и фиксации древних археологических памятников региона. Эти горные массивы являются основной транспортной магистралью Хантауского транзитного коридора между Центральным Казахстаном и Жетысу. Как было установлено, природно-географические особенности Шу-Илейского эрозийнотектонического низкогорья с прилежащими равнинами, являясь северо-

западными отрогами Тянь-Шаня, по своим параметрам гораздо ближе относятся к Казахскому мелкосопочнику [Воякин и др., 2019, с. 127]. Это своеобразие характеризуется тем, что растительный и животный мир региона соответствует полупустынным и степным районам Казахстана в большей мере, чем горно-предгорным. Это не могло не сказаться на особенностях хозяйственно-культурного развития древнего населения Шу-Илейского низкогорья.

Работа выполнена при финансовой поддержке Комитета науки Министерства образования и науки Республики Казахстан, ИРН проекта АР05135512 


\section{Методика исследований}

Основной задачей археологической разведки этого сезона стало выявление структуры археологических комплексов и выяснение характера расселения и хозяйственной модели древних жителей региона. Методика исследований, рассмотренная нами детально в предыдущих работах [Воякин и др., 2019, с. 126-133; Горячев, Ильин, 2019, с. 150-164], включала в себя сбор и анализ имеющихся архивных и библиографических материалов, топографических карт, дешифровки космических снимков региона, натурного обследования объектов и камеральной обработки полученных результатов и их систематизацию.

Обследованы межгорные долины вплоть до правобережья реки Шу и склоны гор Хантау, Айтау, Кулжабасы и Киндыктас. В результате археологической разведки выяснилось, что древние памятники расположены в регионе неравномерно. Наиболее плотное их скопление зафиксировано вдоль юго-западных и северовосточных склонов хребта Киндыктас и в южной части гор Кулжабасы. В горах Айтау памятники фиксируются на выходе из ущелий и в горных долинах близ родников.

\section{Описание материала гор Хантау}

Дополнительная археологическая разведка памятников эпохи палеометалла и раннего железного века гор Хантау позволила дополнить археологическую карту микрорайона (рис. 1). Разведка затронула верховья рек Котыр и Сарыбулак, плато Шубар и примыкающие к нему отдельные ущелья, а также ущелья Сункар и территории, прилегающей к горе Костобе юго-западных склонов хребта. Всего обнаружено свыше 20 новых археологических памятников: три новых скопления древних петроглифов, обследовано поселение Костобе и три новых поселения древних скотоводов, а также 15 могильников эпохи бронзы и раннего железного века.

Новые поселения отмечены в верховьях отдельных ущелий, берущих свое начало от плато Шубар, где находятся истоки рек Котыр и Сарыбулак. Помимо двух стоянок в боковых отщелках ущелья Сункар, наиболее крупное поселение обнаружено в верховьях ущелья Багыл по левому берегу одноименного ручья - левого притока реки Котыр. Здесь зафиксированы остатки около 10 древних и средневековых полуземлянок в виде неглубоких западин и выровненных площадок. Размеры жилых и хозяйственных построек от $6 \times 4$ м до $10 \times 8$ м. Они устроены на относительно ровной площадке вдоль берега ручья в северо-западной части достаточно широкой для горной местности долины. Общая площадь поселения около 6000 м². Площадки под хозяйственные строения расположены большей частью на противоположном от поселения берегу ручья (рис. 2, 1-2).

В 300-500 м вверх по ручью по правому берегу ручья Багыл в 10,5-10,8 км к СВ от ст. Хантау обнаружены два скопления древних петроглифов, устроенных на шести скальных грядах двух сопок по северному борту долины (рис. 2, 3-8). Наскальные рисунки расположены на плитах с юго-западной и южной экспозицией. Изображения бронзового века отличаются степенью патинизации и иконографией, близкой к петроглифам тамгалинского стиля [Марьяшев, Горячев, 2002, с. 35]. Фигуры животных раннего железного века выполнены, как правило, в традициях 
Горячев А.А., Потапов С.А., Ильин Р.В. Результаты археологической разведки древних памятников в горах Хантау, Айтау и Киндыктас

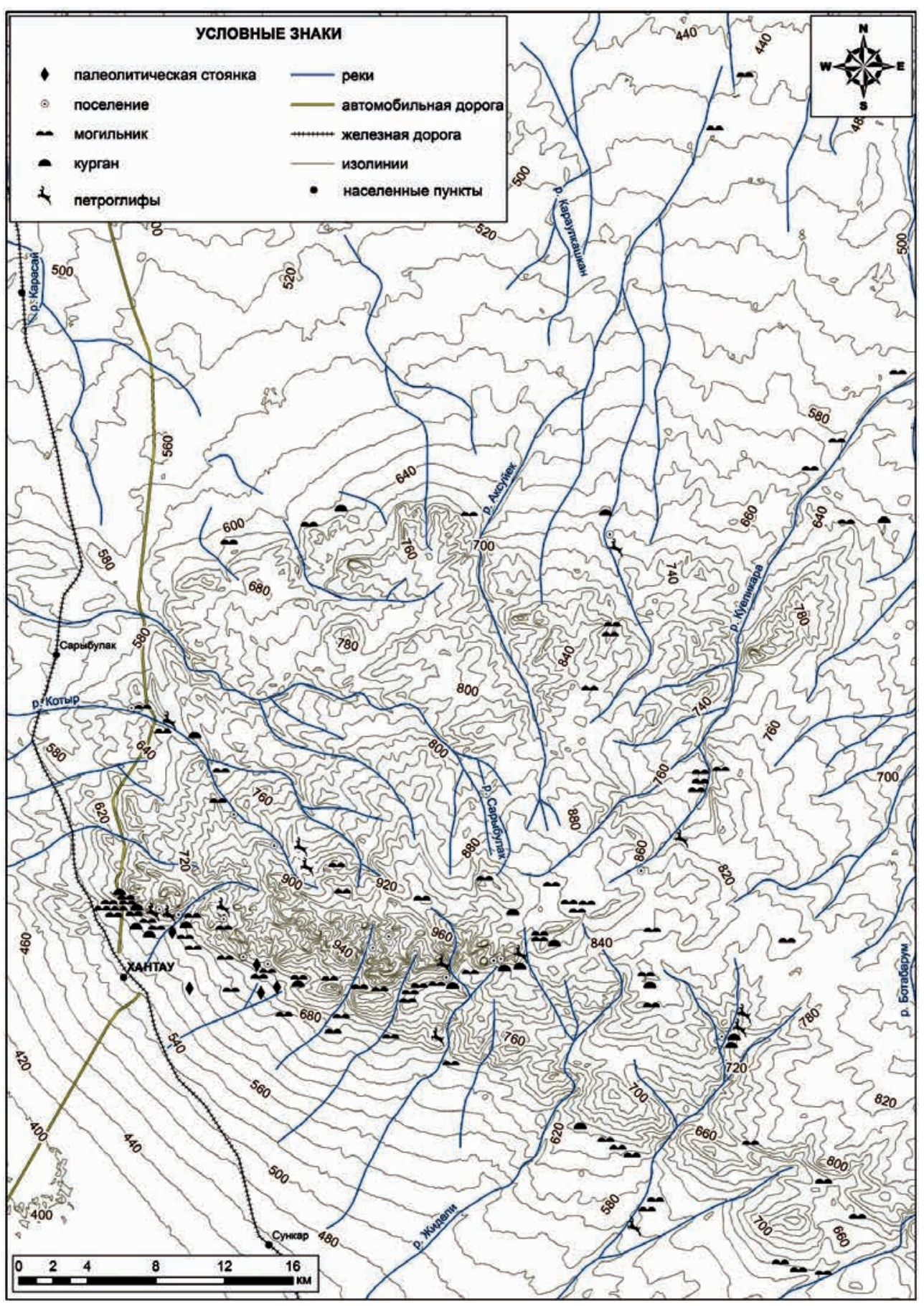

Рис. 1. Топографическая карта расположения археологических памятников в горах Хантау

Fig. 1. Topographic map of location of archaeological monuments in Khantau 


\section{ҚАЗАҚСТАН АРХЕОЛОГИЯСЫ №v 1 (7) 2020}
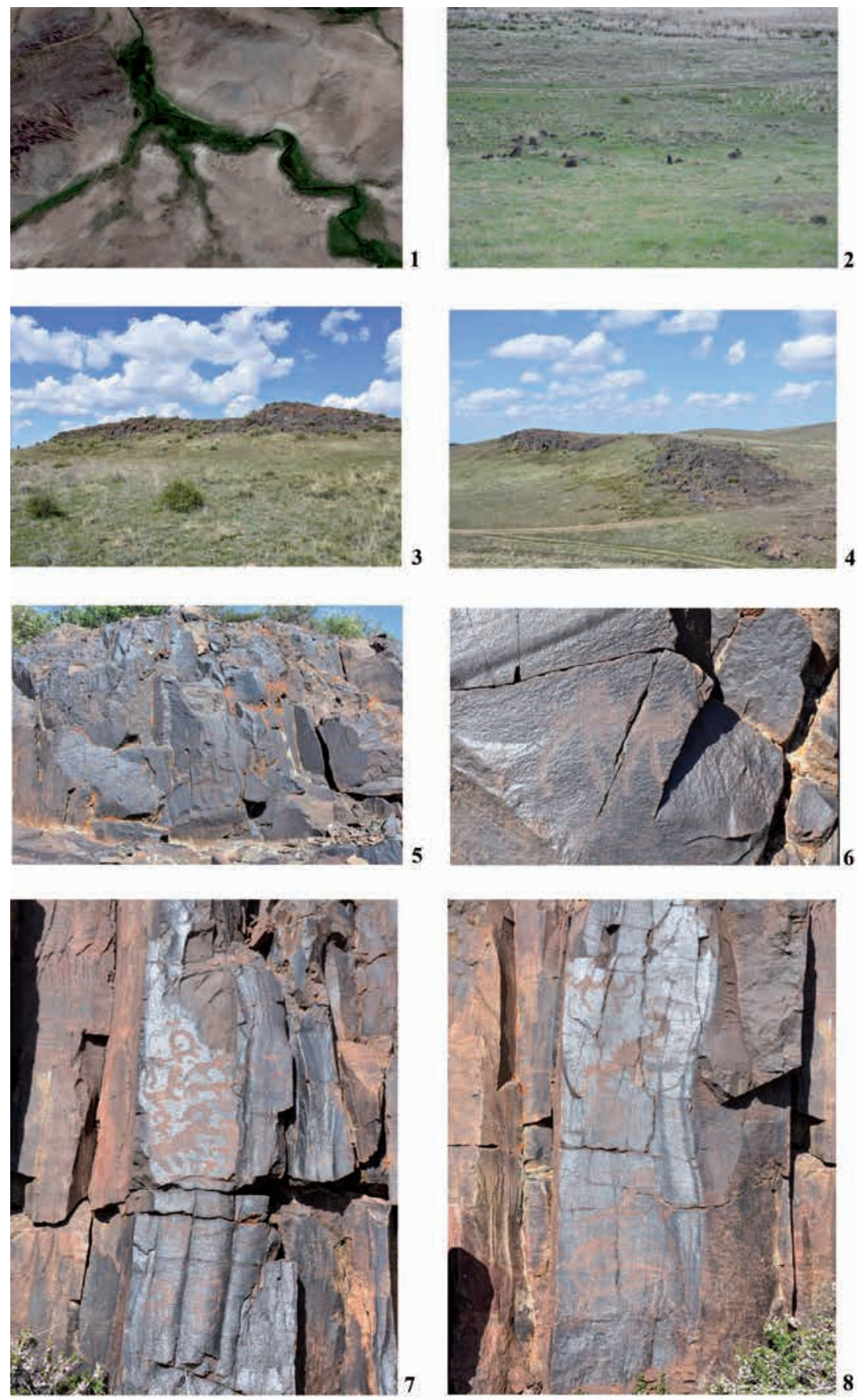

Рис. 2. Поселение и петроглифы в верховьях реки Котыр: 1 - поселение Багыл на космоснимке; 2 -хозяйственные строения в районе поселения Багыл; 3, 4-скальные гряды с петроглифами по правому берегу ручья Багыл; 5, 6-изображения верблюдов

эпохи бронзы; 7 - композичия с изображением людей и животных эпохи бронзы;

8 -изображения животных эпохи бронзы. Фото авторов

Fig. 2. Settlement and petroglyphs in riverhead Kotyr: 1 - settlement Bagyl in space image; 2 -farm buildings near settlement Bagyl; 3, 4-rocky ridge on the right bank of the stream Bagyl; 5, 6-images of camels of bronze epoch; 7 - composition with images of people and animals of bronze epoch; 8 -images of animals of bronze epoch. Authors's photos 

древних памятников в горах Хантау, Айтау и Киндыктас

скифо-сибирского звериного стиля. Техника нанесения рисунков на скалы точеная выбивка с прошлифовкой внутри. Среди рисунков встречаются изображения козлов, архаров, оленей верблюдов, лошадей; антропоморфные фигуры представляют лучников, всадников, людей в ритуальных позах. Зафиксированы знаки колесницы и геометрические фигуры.

В полевом сезоне 2019 г. в горах Хантау были проведены полевые исследования на поселении Костобе 2, снят топографический план (рис. 3, 1-2). Оно находится в 2,5 км вглубь ущелья по северному склону горы Костобе и расположено на ровной площадке древней морены по правому берегу родника. По склону площадки в массовом порядке фиксируются фрагменты костей и керамики эпохи бронзы, раннего железа и средневековья. Поселение состоит из средневековой усадьбы с хозяйственными постройками и серии заплывших полуземлянок эпохи бронзы и раннего железного века (рис. 3, 3-5).

В ходе исследований на скалах близ поселения обнаружена небольшая группа петроглифов эпохи бронзы и раннего железного века. Сделан контрольный шурф внутри средневекового жилища на глубину 100-110 см размерами $100 \times 100$ см (рис. 3, 6-7). Вдоль северо-западной стенки жилища была открыта каменная кладка фундамента, устроенная из двух рядов камней, уложенных плашмя в 3-4 слоя. Общая толщина основания фундамента 60 м, глубина 50 см. Камни были укреплены мелкими плитками-подпорками и скреплены глинистой обмазкой, что соответствует средневековым традициям глинобитных домов в регионе. В ходе раскопок и на поверхности поселения обнаружены фрагменты древней и средневековой керамики, кости животных и каменные отщепы (рис. 3, 8). Результаты дополнительных исследований выявили, что следы современного вмешательства на территории памятника отсутствуют. Средневековая усадьба полностью перекрыла всю территорию древней стоянки от эпохи палеометалла до раннего железного века, что предполагает его дальнейшее исследование перспективным.

Описание материала гор Кулжабасы и Айтау

Основная археологическая разведка древних комплексов была проведена в районе хребтов Киндыктас, Кулжабасы и в горах Айтау. Дешифрировка космических снимков позволила выявить на исследуемой территории около 500 потенциальных археологических объектов, большая часть из которых (436) предположительно являются курганными могильниками (рис. 4, 1-2). Многочисленные исследования комплекса археологических памятников гор Кулжабасы показали необычайно плотное заселение этого микрорайона по сравнению с близлежащими территориями (рис. 4, 3). Этот факт способствовал созданию одного из наиболее крупных скоплений древних наскальных изображений на территории Южного Казахстана и Жетысу. Датировка наиболее древних из них периодами энеолита и ранней бронзы [Байпаков, Марьяшев, 2004; Сала, 2004; Марьяшев, Железняков, 2013, с. 18-20; Сала, Деом, 2019; Садуакасулы и др., 2017] позволяет считать, что горы Кулжабасы на данном этапе играли ключевую роль в развитии сезонных миграций и торговых путей в регионе.

$$
\text { Археологическая разведка }
$$

2019 г. должна была ответить на во- 


\section{ҚАЗАҚСТАН АРХЕОЛОГИЯСЫ № 1 (7) 2020}
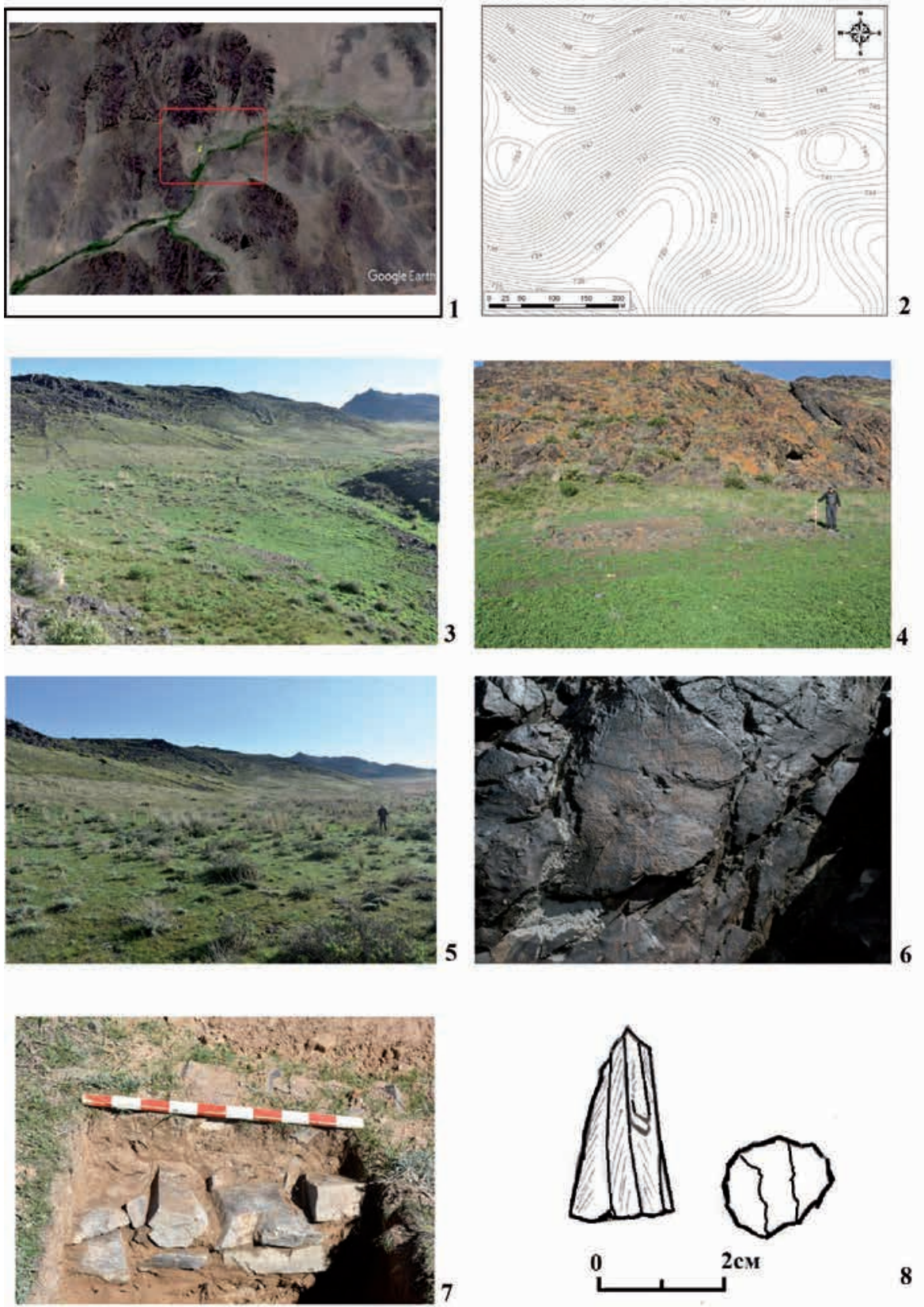

8

Рис. 3. Древнее поселение Костобе 2 юго-западных склонов гор Хантау: 1 -территория поселения на космоснимке; 2 - топографический план поселения; 3 - вид поселения на северо-восток; 4 -средневековое домостроение в западной части поселения; 5 - площадка с древними полуземлянками; 6-nетроглифы эпохи бронзы на скалах над поселением; 7 - контрольный шурф в западной части поселения;

8 - нуклеус неолитического времени

Fig. 3. Ancient settlement Kostobe 2 in South-West slopes of Khantau: 1 -territory of the settlement in space image; 2 - settlement's topographic plan; 3 -settlement's view to the North-East; 4 -Medieval building in Western part of settlement; 5 - field with Ancient pit houses; 6 -petroglyphs of the bronze epoch on the rocks above the settlements; 7 - control hole in Western part of the settlement; 8 -nucleus, Neolithic age 
Горячев А.А., Потапов С.А., Ильин Р.В. Результаты археологической разведки древних памятников в горах Хантау, Айтау и Киндыктас
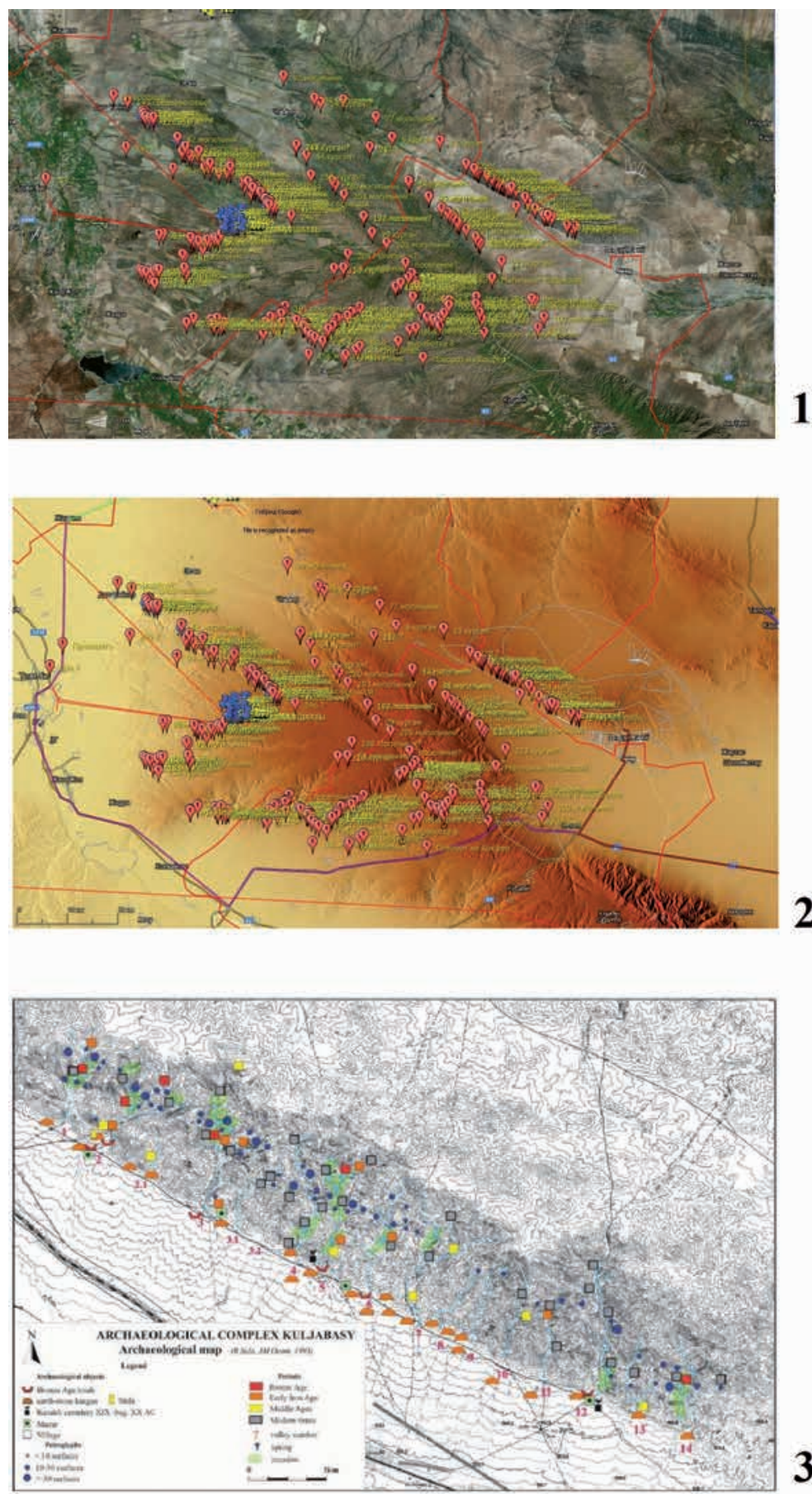

Рис. 4. Карты расположения археологических памятников в горах Киндыктас и Кулжабасы: 1, 2 - расположение потенциальных археологических памятников на космоснимке (1) и на физической карте (2); 3 - карта расположения археологических памятников в западной части гор Кулжабасы (по: [Сала, Деом, 2016])

Fig. 4. Map of location archaeological monuments in Kindyktas and Kuljabasy mountains:

1, 2 - location of possible monuments in space image (1) and in physical map (2);

3 - map of location of archaeological monuments in Western part of Kuljabasy mountains (by: [Sala, Deom, 2016]) 
прос о возможном существовании маршрутов к горам Кулжабасы от гор Хантау через горные ущелья и долины Шу-Илейских гор. В ходе разведки выявлена ситуация, при которой древние поселения в этом районе располагались в ущельях близ родников, многие из которых функционируют до сих пор. Около 10 древних поселений отмечены в верховьях рек Тесик и Жынгылды и в долине Анкелды (рис. 5, 1-2). Поселения расположены на выровненных площадках близ ручьев под скалистым крутым склоном с петроглифами. На поверхности прослеживаются контуры жилищ прямоугольной формы, размерами от $6 \times 5$ м до $9 \times 7$ м. В структуре поселений отмечаются 2-3 жилые площадки и каменные конструкции загонов для скота. Древние строения часто перекрыты более поздними конструкциями стоянок средневековой эпохи и Нового времени. Поселения представляют традиционные для региона зимовки скотоводов для отдельных малосемейных групп.

Петроглифы эпохи палеометалла на скалах близ древних поселений обычно представляют собой невыразительные рисунки с изображением животных - козлов, архаров, быков, лошадей, верблюдов и достаточно примитивные антропоморфные фигуры. В каждой группе прослеживается от 5-6 плит до нескольких десятков плоскостей с древними рисунками (рис. 5, 3-4). Среди композиций преобладают сцены охоты, выпаса скота, отмечены несколько сцен с изображением людей в ритуальных позах. Всего отмечено 16 групп петроглифов, наиболее интересные из них сосредоточены в районе долины родника Анкелды и реки Жынгылды.

Основную часть древних могильников составляют курганы и кур- ганные группы раннего железного века. Они расположены обычно на вершинах сопок или возвышенностях широких долин. Основная масca насыпей курганов сферической или уплощенной формы, сложены из земли и камней, размерами от 3-4 до 10-12 м. Наиболее крупные курганы, диаметром от 20 до 30 м, в этой части Шу-Илейских гор обнаружены в районе ст. Бель, ближе к выходу из горных плато в долину Кулыкбайсай, расположенную между хребтами Кулжабасы и Киндыктас (рис. 5, 5-б).

Могильники эпохи бронзы (4) обнаружены в долинах Тесик, Анкелды и по берегам реки Жынгылды. Они расположены на возвышенностях относительно ровных долин без водных источников. Площадь таких кладбищ составляет от 4000 до 25000 кв. М, что свидетельствует о длительности использования данной территории в эпоху бронзы. Погребальные конструкции эпохи бронзы насчитывают несколько десятков каменных оград округлой, квадратной и прямоугольной форм в каждом могильнике, размерами от $3 \times 3$ м до $8 \times 7,5$ м или диаметром 3-4 м (рис. 5, 7-8). К оградам сделаны пристройки с детскими захоронениями. Внутри оград прослеживаются конструкции захоронений, обычно в каменных ящиках прямоугольной формы, размерами от $0,6 \times 0,4$ м до $2 \times 1,2$ м. Могилы ориентированы по оси 3 (Ю3) - В (СВ).

Описание материала гор Киндыктас

Натурные обследования для проверки всего массива данных производились на северо-восточных склонах в урочище Ойжайлау/ОйДжайляу и ущелье Мадьярсай и югозападных склонах гор Киндыктас по территории водного бассейна р. Как- 
Горячев А.А., Потапов С.А., Ильин Р.В. Результаты археологической разведки древних памятников в горах Хантау, Айтау и Киндыктас
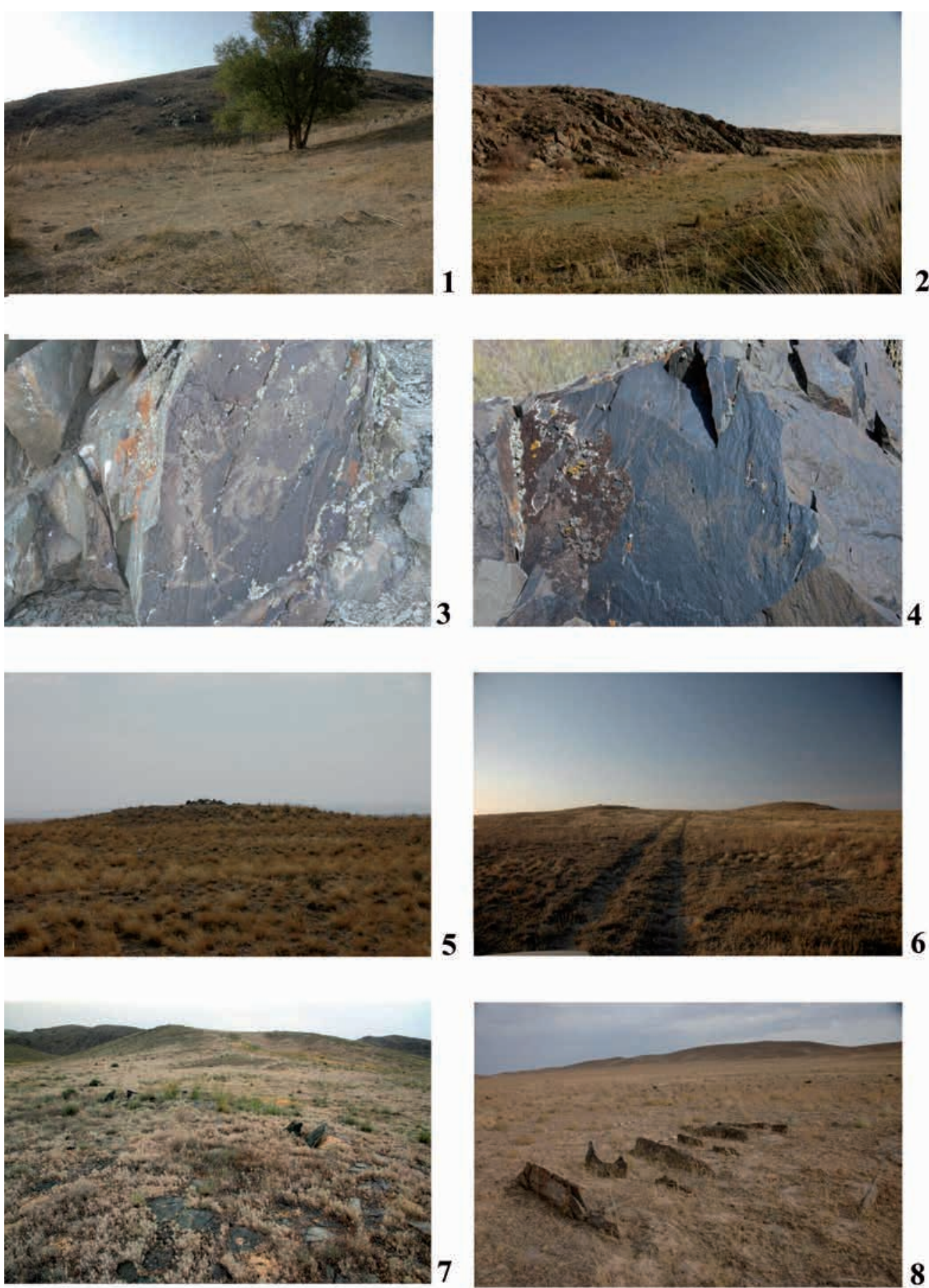

Рис. 5. Древние памятники эпохи бронзы и раннего железного века в горах Айтау:

1, 2 - площадки древних поселений; 3, 4-наскальные рисунки бронзового века;

5, 6-курганы раннего железного века; 7, 8-каменные ограды и ящики эпохи бронзы

Fig. 5. Ancient monuments of bronze epoch and the Early Iron age in Aytau mountains: 1, 2 -fields with Ancient settlements; 3, 4-rock images of the bronze epoch;

5, 6- burial mounds of the Early Iron age; 7, 8-stone fencing and boxes of bronze epoch 
патас. В итоге в долине рек Какпатас, Согынды и их притоков было обследовано 156 памятников археологии. Всего было выявлено 24 поселения, свыше 120 могильников, восемь горнорудных выработок месторождений Согынды и Какпатас, четыре скопления петроглифов. Плотность скопления древних памятников вдоль югозападных склонов хребта Киндыктас позволяет считать данный район наиболее перспективным для дальнейших исследований.

Выяснено, что основная группа поселений представляла собой небольшие семейно-родовые поселки от двух до 10 подворий. Поселения располагались внутри ущелий от 500 м вглубь до 2-3 км. Контрольные сборы на трех объектах показали, что их хронологический диапазон в эпоху палеометалла - от бронзового до раннего железного века. Характер поселений определялся их структурой. Поскольку рельеф местности позволял попасть к ним свободно по невысоким вершинам и широким долинам Киндыктаской возвышенности: имеются основания отнести их к поселениям древних скотоводов (рис. 6, 1-2). Они располагались внутри горных ущелий, по боковым отщелкам близ скальных групп с южной экспозицией и представляли семейно-родовые стоянки от двух до шести подворий. Жилища представляют собой полуземлянки округлой или прямоугольной форм, размерами от $8 \times 6$ м до $5 \times 4$ м (диаметры округлых строений 5-6 м). Близ жилых помещений фиксируются крупные загоны для скота, размерами от $10 \times 8$ м до $20 \times 16$ м. Стены жилых и хозяйственных конструкций состоят из двух рядов камней.

Серия поселений (8) обнаружена в верховьях рек Какпатас и Со- гынды близ горнорудных выработок (рис. 6, 3-4). Несмотря на наличие признаков скотоводческого поселения (крупные загоны для скота), есть основания считать их поселками древних рудокопов. Они представляют собой небольшие шурфы разных форм на склонах и у подножия горных хребтов и отдельных сопок (рис. 6, 5-6). При визуальном осмотре в них и рядом были зафиксированы меднои железосодержащие куски пород. Близ выработок долины р. Согынды найдено четыре крупных могильника бронзового века, еще один - в срединной части долины - Какпатас 2. Это дает основание считать, что освоение данной территории началось с более доступной согындинской долины, а затем продолжилось в долине реки Какпатас с более сложным рельефом местности. С учетом раннее известных древних месторождений югозападных склонов хребта Киндыктас (Шатырколь, Унгирли, Жайсан) можно отметить, что данный район являлся крупным металлургическим центром эпохи палеометалла на территории Жетысу помимо известного Хантауского горно-металлургического округа [Берденов, 1998].

Если в горных ущельях проживали скотоводы и рудокопы, то на выходе из них найдены поселения земледельцев, привязанные к древним ирригационным системам (рис. 6, 7-9). Такие поселения отличаются и структурно. Они насчитывают до 10 12 жилых помещений, устроенных по берегу ручья в 2-3 яруса. Жилищаполуземлянки фиксируются в виде площадок и западин квадратной и прямоугольной форм, размерами от $5 \times 5$ м до $8 \times 6$ м. На противоположном берегу или вплотную к жилищам примыкали хозяйственные постройки 
Горячев А.А., Потапов С.А., Ильин Р.В. Результаты археологической разведки древних памятников в горах Хантау, Айтау и Киндыктас
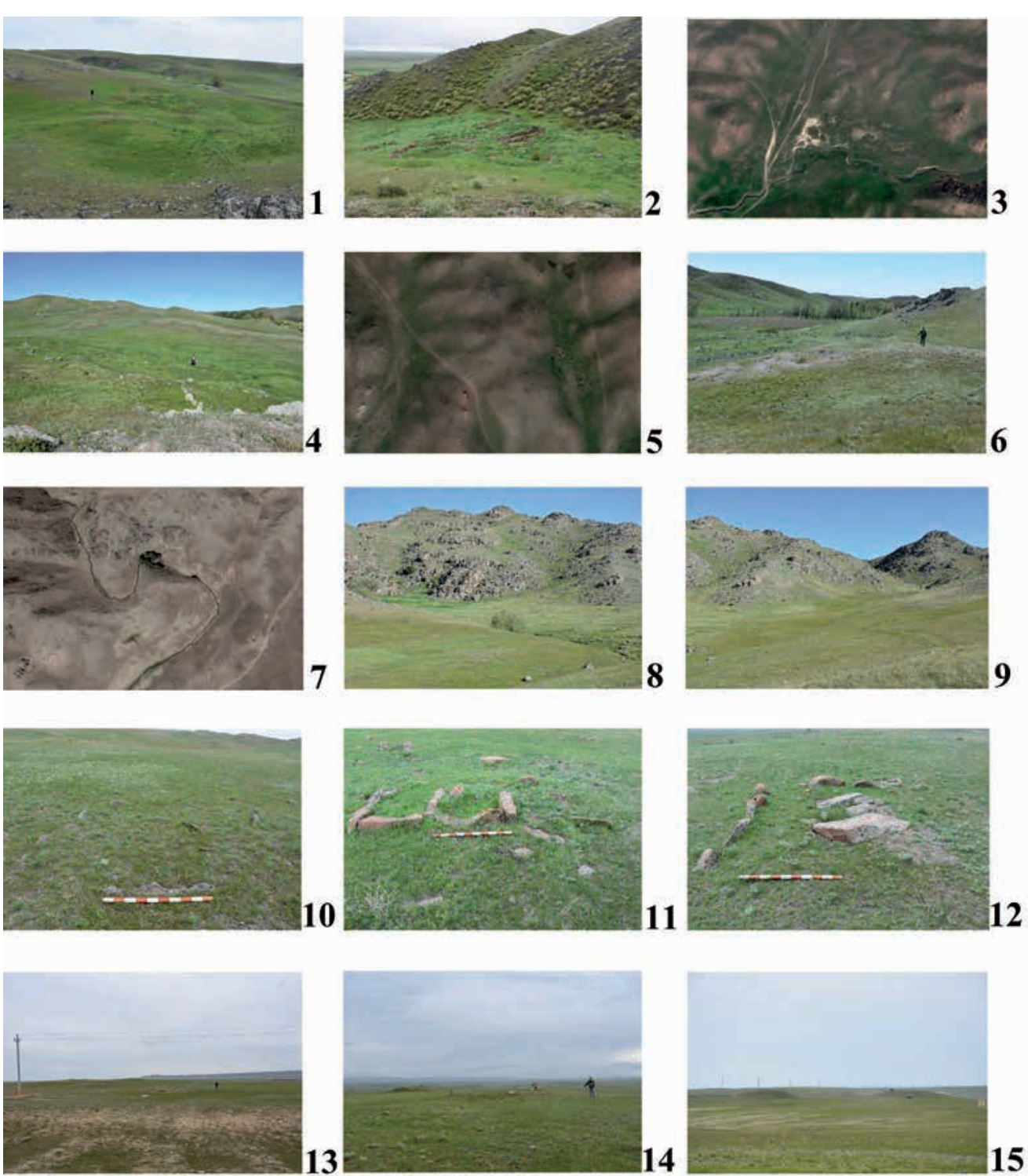

Рис. 6. Древние памятники эпохи бронзы и раннего железного века юго-западных склонов хребта Киндыктас в долинах рек Согынды и Какпатас:

1, 2- поселения древних скотоводов; 3, 4-поселения близ горных выработок;

5, 6-горные выработки в долине реки Какпатас; 7, 8 - поселение земледельиев

у юго-западных склонов гор; 9 - поливной арык от древнего поселения;

10-12 - каменные ограды и ящики эпохи бронзы; 13, 14 - курганы раннего железного века; 15 - «иарские» курганы по левому берегу реки Какпатас

Fig. 6. Ancient monuments of bronze epoch and the Early Iron age on South-Western slopes of Kindyktas ridge in the valleys of Sogyndy and Kakpatas rivers:

1,2 - settlements of Ancient cattlemen; 3, 4-settlements near mine workings;

5, 6- mine workings in Kakpatas river valley; 7, 8 - settlement of farmers near South-

Western slopes of mountains; 9 - irrigation ditch of Ancient settlement;

10-12 - stonefencing and boxes of bronze epoch; 13, 14 - burial mounds

of the Early Iron age; 15 - "royal" burial mounds on left Kakpatas riverbank 
(кладовые, сараи), размерами от $3 \times 3$ м до $5 \times 4$ м. От родника проложен арык, выводивший воду на поля. В горной местности это обычно небольшие чеки, ограниченные невысоким валом до 1 м - защита от потравы посевов скотом.

Могильники бронзового века устраивались на выходе из небольших горных саев или на возвышенностях по берегам крупных ручьев и рек и представляли собой цепочки каменных оград или курганов-оград (рис. 6, 10-12). Ограды квадратной или прямоугольной формы, реже округлой, сложены из крупных каменных плит, вкопанных на ребро или уложённых плашмя. Размеры оград от $3 \times 3$ м до $7 \times 4$ м, диаметр - 3-4 м. Некоторые ограды составлены в цепочки, ориентированные по оси С-Ю. Внутри оград фиксируются одиночные или парные захоронения в каменных ящиках или цистах прямоугольной формы, размерами от $1 \times 0,5$ м до 2,2×1,2 м. Погребальные сооружения ориентированы по оси 3-В с небольшими отклонениями к югу. Такие сооружения зафиксированы в 12 могильниках обследованного микрорайона.

Как правило, продолжением этих могильников являлись курганы раннего железного века, выстроенные в серии цепочек (рис. 6, 13-14). Количество насыпей в таких могильниках варьируется от 3-4 до нескольких десятков. Наиболее многочисленные объекты сосредоточены по берегам крупных рек Какпатас и Согынды. Насыпи курганов раннего железного века сферической или уплощенной формы сложены из земли и камней, обычно с кольцевой каменной оградой по периметру. Параметры насыпей в диаметре от 3 до 20 м, высотой от 0,1 до 2 м.
Крупные «царские» курганы, диаметром от 25 до 50 м, фиксировались на горных перевалах, по берегам реки Какпатас и на выходе из предгорной долины в пойму реки Шу. Они являлись основой для создания вокруг них могильников численностью свыше 100 погребальных объектов (рис. 6, 15). Крупные погребальные комплексы эпохи палеометалла и раннего железного века отмечены у югозападных склонов гор Киндыктас в долинах рек Какпатас, Согынды, Унгирли, Шатырколь и Шокпар.

Физико-географические особенности северо-восточных склонов и северо-западной оконечности хребта Киндыктас отразились и в структуре древних памятников. Поселения и могильники, как правило, устроены внутри нешироких ущелий и на горных плато, как в ущельях Йирсу, Мадьярсай, Карасай, Шокпар, Кызылсай, Киндыктас, так и в урочище Ойжайлау. В ущелье Йирсу обнаружено три древних жилых комплекса, в ущельях Кызылкора, Киндыктас и Шокпар по два, в узких горных саях Карасай и Кызылсай по одному (рис. 7, 1-3). Поселения состоят как из серии древних жилищ, так и хозяйственных комплексов средневековья. Их общая площадь составляла от 500 до $4000 \mathrm{M}^{2}$.

На поверхности отмечаются выровненные площадки под жилые и хозяйственные конструкции, размерами от $5 \times 4$ м до $10 \times 8$ м, расположенные в несколько ярусов относительно берега ближайшего ручья. Контуры строений фиксируются по фрагментам проступающих каменных оснований фундаментов стен. В каждом поселении просматриваются от 4-5 до 12 древних жилых конструкций. Конструкции эпохи бронзы отличаются традицией устройства основа- 
Горячев А.А., Потапов С.А., Ильин Р.В. Результаты археологической разведки древних памятников в горах Хантау, Айтау и Киндыктас
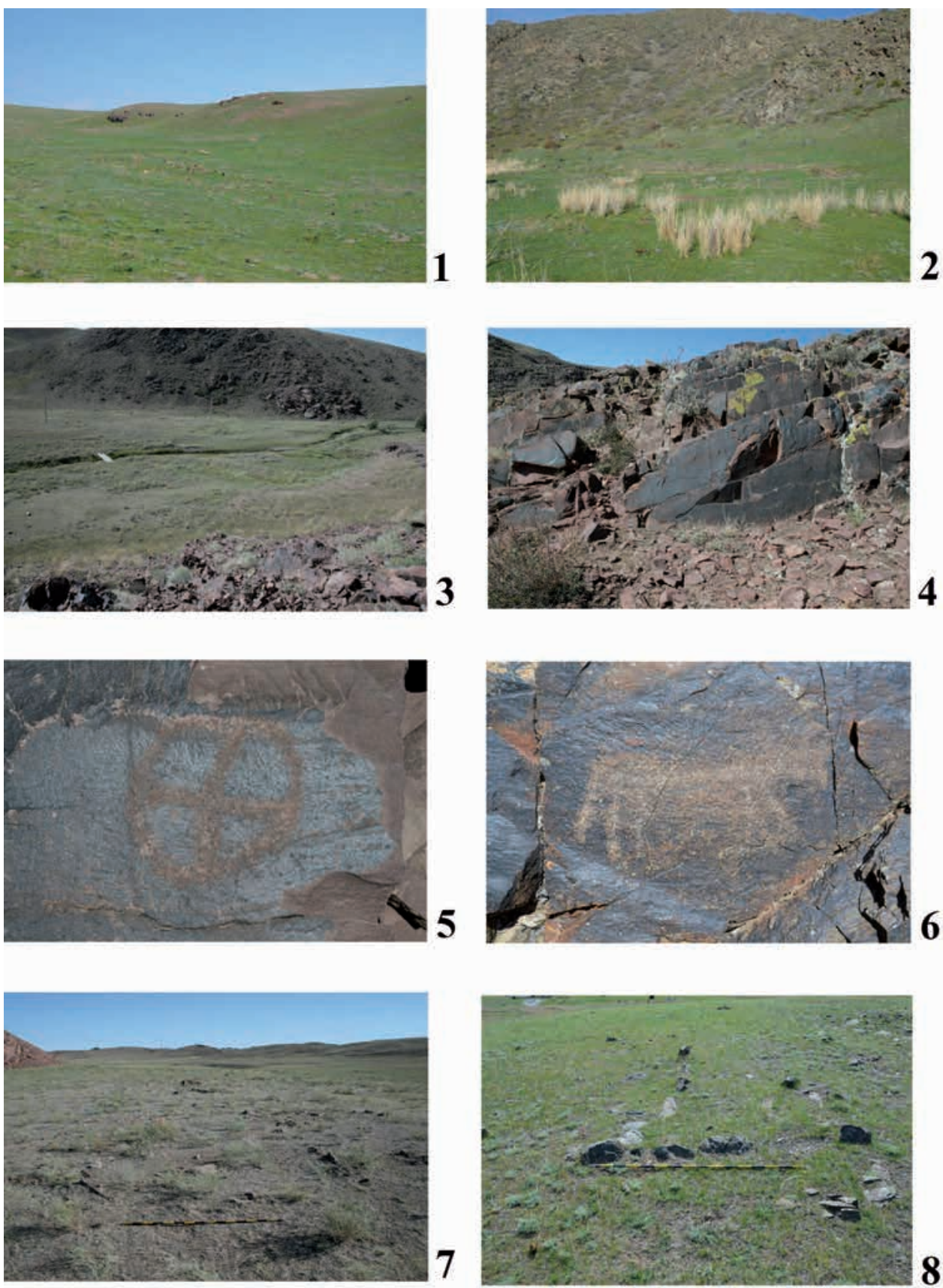

Рис. 7. Древние памятники эпохи бронзы северо-восточных склонов и северозападной оконечности хребта Киндыктас: 1-3-древние поселения в ущельях Йирсу (1), Карасай (2) и Кызылкора (3); 4-6- петроглифы близ поселений в ущельях

Шокпар (4), Кызылккора (5) и Киндыктас (6); 7, 8-могильники бронзового века в ущельях Шокпар (7) и Карасай (8)

Fig. 7. Ancient monuments of bronze epoch of North-Eastern slopes and Norh-Western part of Kindyktas ridge: 1-3 - Ancient settlements in gorges: Ersu (1), Karasai (2), Kyzylkora (3); 4-6-petroglyphs near settlements in Shokpar gorge (4), Kyzylkora (5) and Kindyktas (6); 7, 8-burials of bronze epoch in gorges Shokpar (7) and Karasay (8) 
ний фундаментов в один ряд камней. В раннем железном веке кладки оснований фундаментов жилищ состояли из двойного ряда камней, сами жилые помещения врезались в склоны ущелья. Близ поселений отмечены рисунки на скалах (рис. 7, 4-6).

Могильники устраивались обычно на выходе из ущелий или на ровных площадках по берегам ручьев. Погребальные сооружения эпохи бронзы представлены цепочками каменных оград округлой или квадратной форм. Размеры оград $4 \times 4$ м или до 4 м в диаметре. Внутри оград видны конструкции погребений в виде каменных ящиков и цист (рис. 7, 7-8). Могилы, размерами от $80 \times 60$ см до $2 \times 1,2$ м, ориентированы по оси Ю3СВ. Всего прослеживается от 10 до 50 конструкций.

На северо-восточных склонах детально обследованы урочище Ойжайлау и ущелье Мадьярсай, где документировано около 50 памятников эпохи палеометалла и раннего железного века, из них 14 древних поселений, свыше 30 могильников, пять скоплений петроглифов и два святилища из камней с чашевидными лунками [Горячев, Ильин, 2019]. Из всех районов хребта Киндыктас наиболее исследованным является урочище Ойжайлау (рис. 8, 1), первые сведения об археологических памятниках которого появились в конце XIX в. [Краснов, 1888].

Современные исследования древних памятников микрорайона проводились Семиреченской археологической экспедицией (рук. К. А. Акишев), экспедицией КазПИ им. Абая (рук. А. Н. Марьяшев) и Ой-Джайляуским отрядом Института археологии им. А. Х. Маргулана (рук. Ю. А. Мотов) в 1980-1990-е годы и в 2000-е гг. Основные работы производились на могильниках бронзового и раннего железного веков, тюркских погребально-поминальных комплексах и наскальных рисунках урочища [Марьяшев, Горячев, 1992; 1993; 2002; Мотов, 2011б]. Результаты исследований показали, что данный историкогеографический микрорайон играл одну из ключевых ролей в формировании облика древних культур от эпохи палеометалла до раннего средневековья.

В западной части урочища в долине реки Узынсу расположено наиболее крупное скопление наскальных рисунков (рис. 8, 2) от эпохи бронзы до средневековья [Медоев, 1979; Марьяшев, Горячев, 2008; Мотов, 2011a]. В районе скал с петроглифами отмечена серия небольших поселков с сохранившимися каменными стенками домостроений позднего средневековья и Нового времени. Ранее в результате контрольных шурфов установлено, что наиболее древние слои этих поселков относятся к эпохе бронзы и раннему железному веку. Серия таких поселений зафиксирована на широких площадках ручьев - притоков реки Узынсу. Всего в урочище отмечено три поселения со слоями эпохи бронзы и 10 раннего железного века, где зафиксированы материалы и конструкции (рис. 8, 3). Могильники эпохи бронзы и раннего железного века устроены на вершинах крупных увалов. К эпохе палеометалла относится пять погребальных комплексов, к раннему железному веку - 10 (рис. 8, 4-5).

В юго-западной части урочища зафиксирован археологический объект, именуемый «Уйтас» (рис. 8, 6-7). Это массивный валун гранитного происхождения юртообразной фор- 
Горячев А.А., Потапов С.А., Ильин Р.В. Результаты археологической разведки древних памятников в горах Хантау, Айтау и Киндыктас
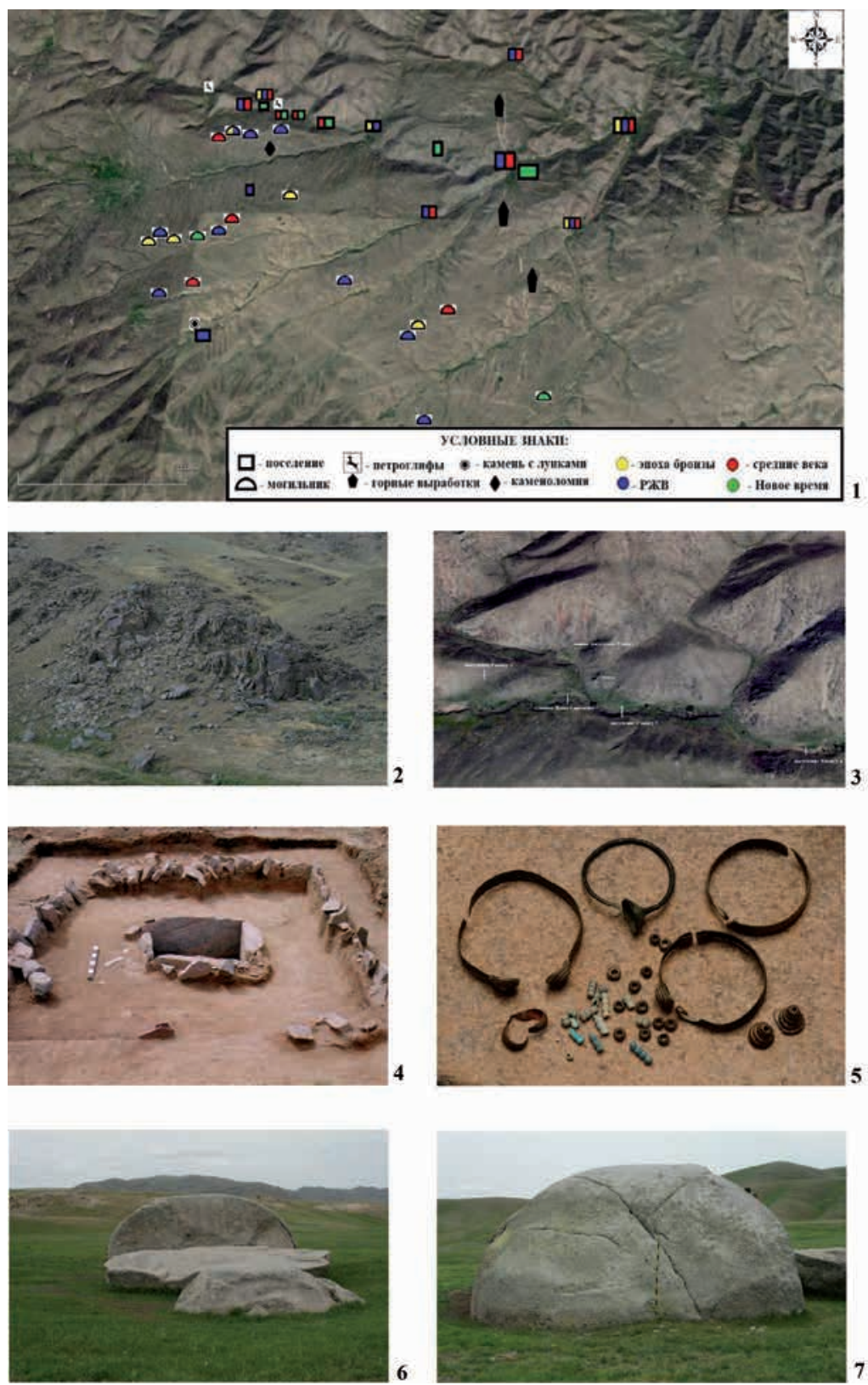

Рис. 8. Древние археологические памятники урочища Ойжайлау:

1 - карта памятников археологии урочища Ойжайлау на космоснимке;

2 - сопка с петроглифами в верховьях реки Узынсу; 3 - поселения эпохи бронзы, раннего железного века и средневековья в долине ручья Узынсу; 4-погребальные конструкции могильника эпохи бронзы Ой-Джайляу-IX; 5 - вещевой материал из могильников бронзового века урочища Ойжайлау; 6, 7 - камень с чашевидными лунками «Уйтас» в цุентральной части урочища Ойжсайлау

Fig. 8. Ancient archaeological monuments of Oyjaylau gorge: 1 - map archaeological monuments of Oyjaylau gorge in space image; 2 - hill with rock images in riverhead of Uzynsu; 3 - settlements of bronze epoch, the Early Iron age and Middle ages in the valley of Uzynsu stream; 4 - burial structures of bronze epoch of Oyjaylau gorge-IX;

5 - material from burials of bronze epoch of Oyjaylau gorge; 6, 7-stone with cup-shaped wells "Yitas" in the center of gorge 
мы, диаметром 7,5 м. Часть валуна отколота с западной стороны и «опрокинута» местом раскола к верху. По боковой части уйтаса насчитываются около 20 чашевидных углублений, диаметром 4-6 см, а по периметру основания валуна отмечена каменная выкладка шириной 30-40 см. В районе камня отмечены площадки квадратной и прямоугольной форм, ограниченные по периметру неглубокими рвами, за которыми устроены каменные ограды, схожие по форме на ограды эпохи бронзы. Вероятно, данный камень использовался в древности в ритуальных целях как своеобразное святилище.

Ущелье Мадьярсай расположено на северо-восточном склоне гор Киндыктас. Его общая протяженность с юго-запада на северо-восток 5,5 км. В центральной части оно раздваивается на узкий каньон одноименного ручья и относительно широкую долину его бокового притока, где находится основная группа древних археологических памятников ущелья (рис. 9, 1). По итогам разведки здесь обнаружено четыре древних поселения и две средневековые усадьбы, в районе которых зафиксировано три скопления наскальных рисунков. Еще одна их группа найдена на вершине сопки, разделяющих ущелье на южный и северный отщелки. Поселения устроены у западных бортов ущелья и в боковых саях, как правило, близ выхода скальных групп, где и отмечены наскальные рисунки (рис. 9, 2-3). По вершинам сопок и увалов и на склонах подошв ущелья отмечен 21 могильник эпохи бронзы (2) и раннего железного века (рис. 9, 4-7). Они представляют собой цепочки каменных оград и каменно-земляных курганов, устроенных как вблизи древних поселений, так и на гребнях водоразделов или горных перевалах.

В отличие от петроглифов урочища Ойжайлау, расположенных компактно, наскальные изображения в ущелье Мадьярсай устроены отдельными небольшими скоплениями от 3-8 фигур на одной-двух плитах до серии разновременных рисунков, устроенных на 6-14 плитах (рис. 10). Среди технических приемов изготовления петроглифов этих периодов преобладает точечная выбивка с прошлифовкой. Всего в ущелье отмечено около 70 петроглифов на 23 скальных плитах или отдельных камнях. Самое значительное по количеству скопление петроглифов обнаружено в верховьях левого притока ручья Мадьярсай по северо-западному борту ущелья. Среди них найдены два знака колесниц (рис. 10, 1-2), композиции с фигурами собак, хищников и людей. Здесь же встречаются сцены с изображением лошадей, кабана и всадника на коне, преследующего хищника. Основную часть изображений составляют образы козлов и архаров, среди которых встречаются отдельные рисунки, выполненные в традициях звериного стиля раннего железного века. Здесь же на гранитном валуне на плоскостях, обращенных вверх, найдено четыре чашевидных углубления, диаметром 5-8 см и глубиной до 1 см. На боковой грани камня высечена фигура козла, выполненная в традициях, характерных для эпохи бронзы данного региона (рис. 10, 3).

Другая группа петроглифов найдена в верховьях бокового сая, примыкающего к основному ущелью с северной стороны. В 100 м перед поселением по правому берегу ручья обнаружен крупный гранитный валун, на верхней грани которого отмечены 
Горячев А.А., Потапов С.А., Ильин Р.В. Результаты археологической разведки древних памятников в горах Хантау, Айтау и Киндыктас
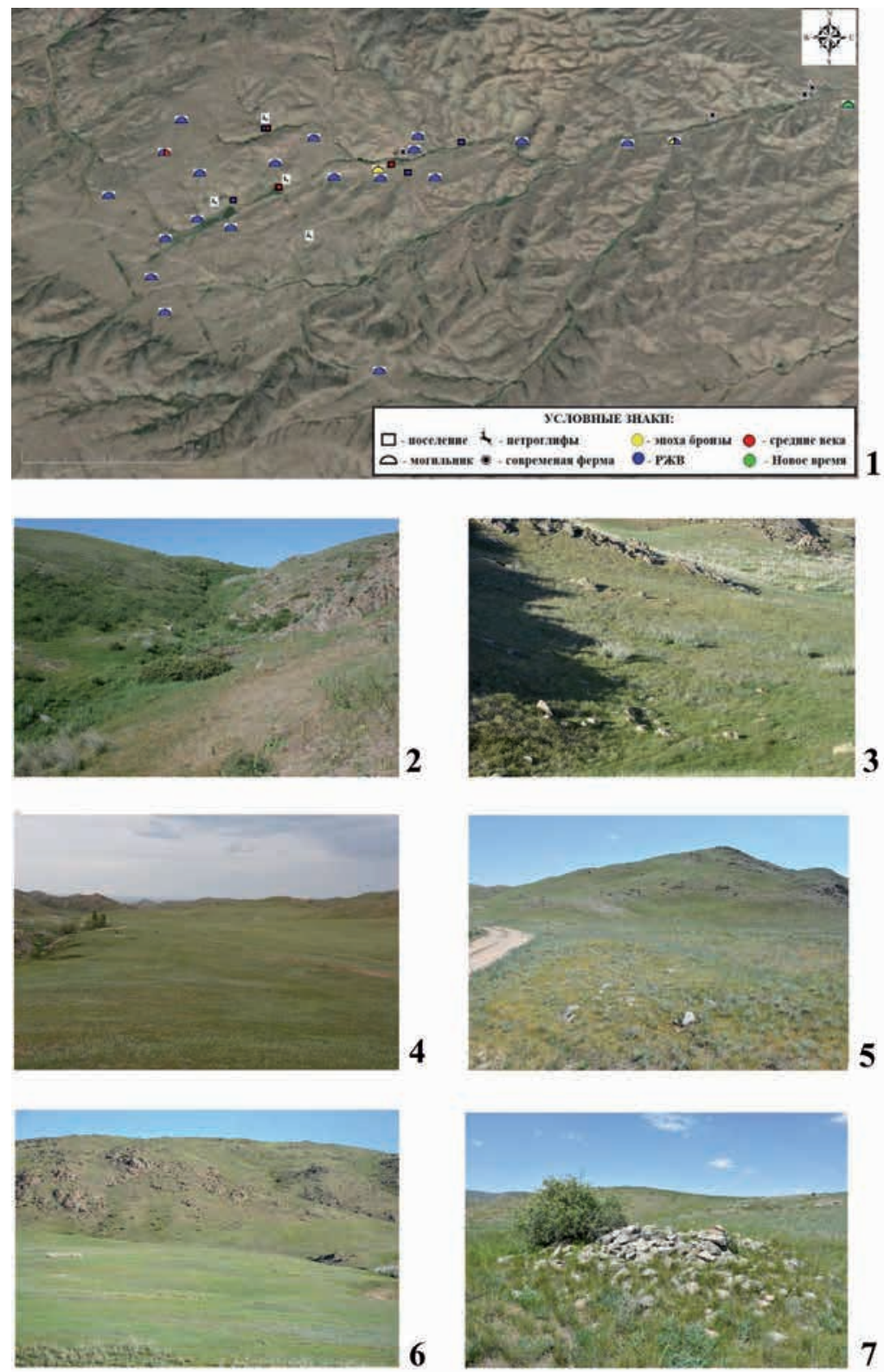

Рис. 9. Древние археологические памятники ущелья Мадьярсай: 1 - карта памятников археологии ущелья Мадьярсай на космоснимке; 2 - древнее и средневековое поселение в боковом сае ущелья Мадьярсай; 3 - древнее поселение в верховьях западного ущелья Мадьярсай; 4 - могильник эпохи бронзы Мадьярсай-I; 5 - могильник эпохи бронзы и раннего железного века в устье ущелья; 6, 7 - могильники раннего железного века в верховьях ущелья

Fig. 9. Ancient archaeological monuments of Madyarsay gorge: 1 - map archaeological monuments of Madyarsay gorge in space image; 2 - ancient and Medieval settlements in

flank gorge in uppers in Madyarsay gorge; 3 - ancient settlement in upper reaches of Madyarsay gorge; 4 - burial of bronze epoch of Madyarsay gorge-I; 5 - settlements of bronze epoch, the Early Iron age in the mouth of the gorge; 6, 7-burials of the Early Iron age in the mouth of the gorge 

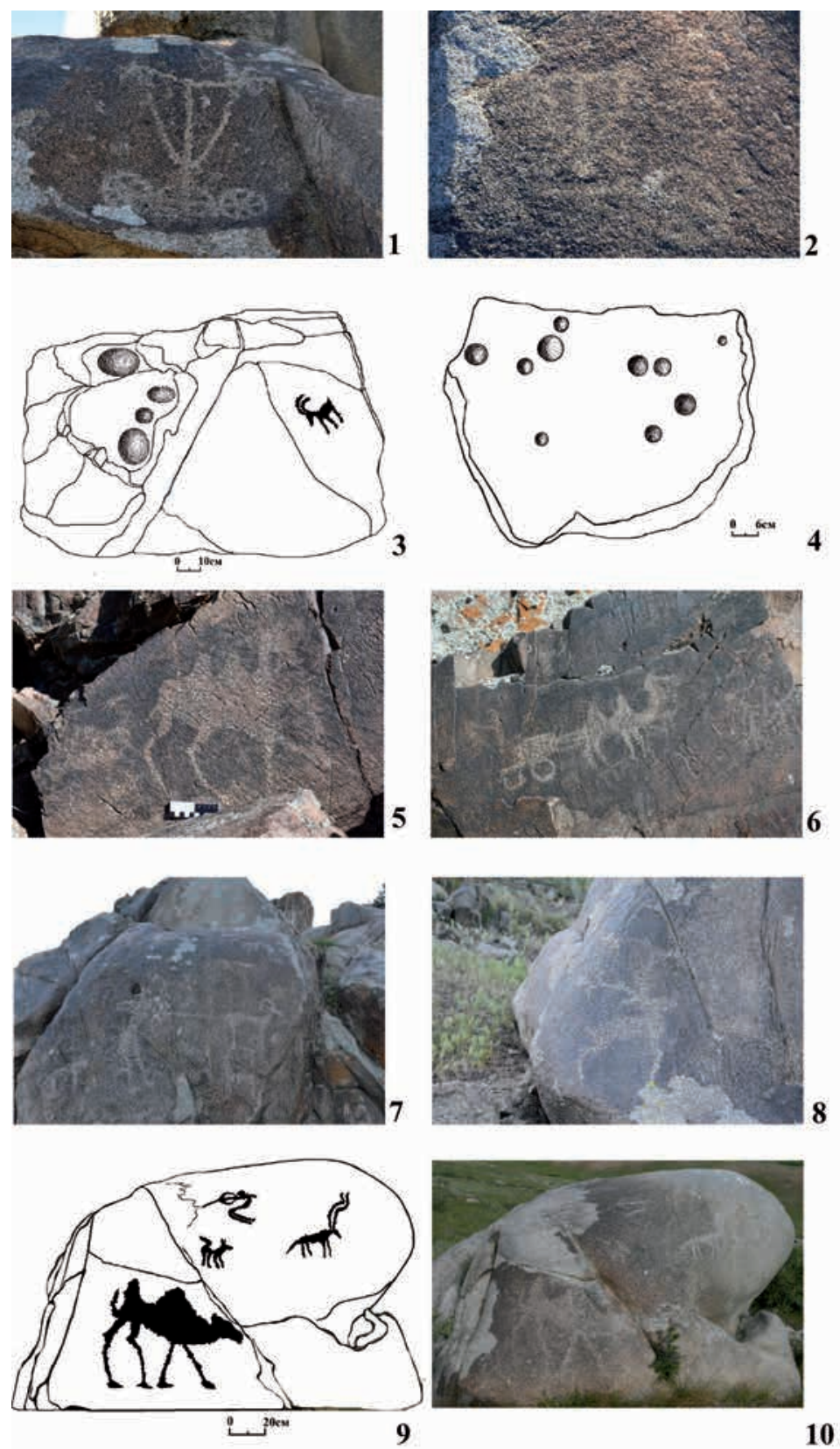

Рис. 10. Древние петроглифы ущелья Мадьярсай: 1, 2-изображения знака колесниць эпохи бронзы в 1 группе; 3, 4-камни с чамевидными лунками близ поселений;

5, 6 - изображения верблюдов раннего железного века в рисунках 2 групnь;;

7 - сиена охоты раннего железного века в петроглифах 3 группы; 8 - фигура оленя раннего железного века в петроглифах 8 группьг; 9, 10 - камень с петроглифами эпохи бронзы на вершине сопки между восточным и западным ущельями Мадьярсай

Fig. 10. Ancient petroglyphs of the Madyarsay gorge: 1, 2-images of the sign of the chariot of the Bronze Age in 1 group; 3, 4 -stones with cup-shaped holes near settlements; 5, 6-images of camels of the Early Iron age in the drawings of group 2; 7 -scene of the hunting of the Early Iron age in petroglyphs of group 3; 8-figure of deer of the Early Iron age in petroglyphs of group 8; 9, 10 - stone with petroglyphs of the Bronze Age on the top of a hill between the East and West gorges of Madyarsay 

древних памятников в горах Хантау, Айтау и Киндыктас

12 чашевидных лунок, диаметром 4-6 см и глубиной 0,5-0,7 см (рис. 10, 4). К древним рисункам здесь можно отнести два сюжета с изображением верблюдов (рис. 10, 5-6). В оном из них показан идущий верблюд, выполненный в характерных традициях звериного стиля раннего железного века. За ним прослеживается неясная фигура животного. Другой сюжет демонстрирует изображение верблюда, запряженного в повозку. Сцена перекрывает более древние неясные рисунки с двумя козлами и хищником (?). Композиция была существенно подновлена в средневековую эпоху, особенно колеса повозки и фигура верблюда.

Третья группа петроглифов найдена близ средневековой усадьбы на скальном выходе. Первая сцена демонстрирует крупную фигуру лучника (50 см в высоту), стреляющего в козла (рис. 10, 7). На другом скальном блоке демонстрируется крупная фигура оленя (40 см) с ветвистыми рогами в скифо-сибирском зверином стиле (рис. 10, 8).

Наскальные изображения четвертой группы зафиксированы на отдельном гранитном валуне и относятся к эпохе бронзы (рис. 10, 9-10). Камень овальной формы размерами $2,2 \times 1,6$ м и высотой 1,1 м. На патинированной нижней части изображен идущий верблюд, в правой верхней боковой грани - бык с длинными вытянутыми рогами. На верхней грани камня показана фигура лучника, стреляющего с колен. Объект охоты неизвестен, так как участок камня перед лучником выщерблен. Фигуры крупных размеров: верблюда - 50 см, быка - 25 см. Высота лучника от головы до ног 30 см. Основные образы наскального искусства бронзового века в пе- троглифах урочища Ойжайлау и ущелья Мадьярсай очень показательны по своей стилистике и характерны для наскального искусства всего региона Шу-Илейских гор.

\section{Обсуждение результатов}

Исследования археологических комплексов эпохи бронзы Хантауского транзитного коридора ставят своей задачей выяснение характера историко-культурного развития древнего населения Юго-Западного Жетысу. Древние поселения в горах Киндыктас представляли собой небольшие семейно-родовые поселки от 2 до 10 подворий, располагавшиеся внутри ущелий. Достаточно регулярно, особенно на северо-восточных склонах и у западной оконечности хребта, близ поселений фиксируются наскальные рисунки. На выходе из ущелий и на возвышенностях межгорных долин, а также по берегам рек юго-западных склонов устроены древние могильники эпохи бронзы и раннего железного века. Новым видом, обнаруженных археологических объектов в регионе являются древние горнорудные выработки. С учетом раннее известных древних месторождений югозападных склонов хребта Киндыктас можно отметить, что данный район являлся крупным металлургическим центром того времени на территории Жетысу.

Исследованные в 2019 г. районы Хантауского транзитного коридора относятся к западным направлениям маршрутов древних миграций между Центральным Казахстаном и Жетысу. Подобные транспортные пути здесь имелись в горной и предгорной зоне хребтов Жайтау-Хантау-АйтауКулжабасы и Киндыктас. Если от хребта Жайтау маршрут пролегал до гор Хантау, где имелась целая система 
родников в пустынной местности, то отсюда возможности для относительно свободного и безопасного прохода к северным склонам Тянь-Шаня было несколько направлений. Первым транзитным маршрутом являлась предгорная полоса гор Айтау от гор Хантау до хребта Киндыктас в районе урочища Шокпар (54 км) и далее в долине реки Шу. Данный маршрут имеет несколько ответвлений маркированных серией известных археологических памятников древности и средневековья.

Характер расположения памятников в исследуемом районе предполагает, что этот путь был наиболее удобным для скотоводческого населения степных районов Казахстана. Ситуация в южных районах гор Хантау и примыкающего к нему хребта Айтау такова, что наиболее южным насыщенным поселениями, могильниками и петроглифами было ущелье Актас, от которого до Шуской долины в районе хребта Киндыктас было менее 30 км. Маловодные юго-западные склоны хребта Айтау и тот период и позднее были заселены слабо. Между ущельями с водными источниками было необходимо пройти 7-10 км. Даже пешком это незначительные расстояния для дневного перехода даже с отягощениями в виде скарба и необходимостью выпаса скота.

Южная оконечность хребта Айтау насыщена серией ущелий с водными источниками - притоками речки Шокпар (Шольадыр, Далакайнар, Дерменсай, Куланшысай и т.д.), долина которой предваряла западные склоны хребта Киндыктас. Через долину реки Шокпар по разным его притокам маршруты расходились к северовосточным и юго-западным склонам и межгорным долинам хребта Киндыктас. Северная ветка маршрута выво44 дила в долину между горами Костобе и Кулжабасы с севера и Киндыктас с юга, где практически каждое ущелье было насыщено древними поселениями и могильниками, составлявшими единые древние хозяйственно-жилые и сакральные комплексы, в том числе и эпохи палеометалла.

Хребет Киндыктас обладает целой серией легко проходимых горных ущелий и плато, через которые было возможно продвижение и расселение в регионе древних скотоводов [Свод памятников ... Кордайский район, 2010; Свод памятников ... Чуйский район, 2012]. К таковым относятся долины Унгирли, Шатырколь, Какпатас, Коккайнар и другие, плато Жайсан, Атжайлау, Ойжайлау и т.д. Данные территории на своих археологических картах фиксируют систему их массового заселения (отмечено свыше 500 археологических памятников), наиболее ранние этапы, которого относятся к эпохе палеометалла (около 70 поселений, могильников и скопления петроглифов).

Вторым основным направлением является выяснение древних маршрутов от гор Хантау до хребтов Костобе и Кулжабасы через горные и межгорные долины. Они начинались от северных склонов гор Хантау, где расположены основные выработки цветных металлов Хантауского горнометаллургического центра эпохи палеометалла [Берденов, 1998, с. 188189]. Ущелья Куйеликара, Ботаборум и Тесик, расположенные в северовосточной и восточной части гор Хантау, были практически непроходимы из-за узких каньонов горных ручьев, которыми они образовывались.

Ближайшим за пределами гор Хантау транзитным потенциалом по 
Горячев А.А., Потапов С.А., Ильин Р.В. Результаты археологической разведки древних памятников в горах Хантау, Айтау и Киндыктас

северной оконечности Шу-Илейских гор обладали урочища Жынгылды и Копалы. По руслам одноименных ручьев через относительно широкие долины древние маршруты выводили на горные плато, структурно схожие с традиционными местами кочевок на территории Казахского мелкосопочника. Древние археологические комплексы эпохи бронзы, обнаруженные в долинах ручьев Тесик, Шолак, Жынгылды и Копалы, отличаются значительным количеством захоронений, которые тянутся на несколько сот метров, что свидетельствует о длительном использовании этой территории. Могильники раннего железного века представляют небольшие группы курганов, которые скорее отмечают отдельные микрорайоны обитания скотоводов того времени.

\section{Bblводbl}

При анализе археологической ситуации по данному маршруту древних миграций прослеживается закономерность следующего порядка. Серия ущелий или крупное горное урочище содержат до десятка древних археологических памятников. Однако при по- следующем передвижении на юг их количество значительно сокращается как на вершинах водоразделов, так в горных ущельях вплоть до следующей группы ущелий. Подобный алгоритм сохраняется вплоть до гор Костобе и Кулжабасы (80-90 км), которые в древности были достаточно плотно заселены. Хребет Кулжабасы расположен на пересечении Копинской и Анрахайской долин, которые своими южными сторонами ограничивались северными склонами гор Киндыктас и отрогов Иле Алатау.

Ключевую роль в системе древних коммуникаций населения Центрального Казахстана и Жетысу через западную часть Хантауского транзитного коридора играли северовосточные и юго-западные склоны горной системы Киндыктаса, наиболее насыщенные памятниками всех исторических периодов. Ведущей транспортной артерией в эпоху палеометалла для данного микрорайона являлась так называемая среди местного населения «Ханская дорога» по маршруту Жайтау-Хантау-АйтауКиндыктас.

\section{ЛИТЕРАТУРА}

1. Байпаков К.М., Марьяшев А.Н. Петроглифы в горах Кульжабасы. Алматы: Институт археологии им. А.Х. Маргулана, 2004. 27 с. [1] с., [43] л. ил., цв. ил., карт; $29 \mathrm{~cm}$.

2. Берденов С.А. Казахстанская горно-металлургическая область // Вопросы археологии Казахстана. Алматы; М.: «Ғылым», 1998. Вып. 2. С. 180-190.

3. Воякин Д.А., Горячев А.А., Ильин Р.В., Дуйсебаева Т.Н. Археологические комплексы эпохи палеометалла в горах Хантау // XI Оразбаевские чтения: матер. междунар. науч.-метод. конф. «Семь граней Великой Степи и актуальные вопросы археологии и этнологии Евразии». Алматы: «Қазақ университеті», 2019. С. 126-132.

4. Горячев А.А., Ильин Р.В. Итоги археологической разведки памятников эпохи палеометалла и раннего железного века в горах Киндыктас // Методы и методология естественных наук в полевых археологических исследованиях: матер. междунар. науч.практ. конф. (г. Алматы, 19 сентября 2019 г.). Алматы: «Қазақ университеті», 2019. C. $150-164$. 
5. Краснов А.Н. Очерки быта семиреченских киргиз // Известия ИРГО. 1888. T. 23. C. $436-481$.

6. Марьяшев А.Н., Горячев А.А. Археологические памятники эпохи бронзы урочища Ой-Джайляу (Семиречье) // Археологические исследования в Казахстане. АлмаАта: КазПИ им. Абая, 1992. С. 3-15.

7. Марьяшев А.Н., Горячев А.А. Вопросы периодизации и хронологии памятников эпохи бронзы Семиречья // РА. 1993. № 1. С 5-19.

8. Марьящев А.Н., Горячев А.А. Наскальные изображения Семиречья. Алматы: Фонд «XXI век», 2002. Изд. 2-е. 264 с.

9. Марьяшев А.Н., Горячев А.А. Петроглифы поздней бронзы и раннего железного века в урочище Ой-Джайляу // Известия НАН РК. Сер. обществ. наук. 2008. Вып. 1 (254). С. 101-109.

10. Марьямев А.Н., Железняков Б.А. Древности Кулжабасы. Алматы: Институт археологии им. А.Х. Маргулана, 2013. 150 с.

11. Медоев А.Г. Гравюры на скалах. Сары-Арка, Мангышлак. Ч. 1. Алма-Ата: «Жалын», 1979. $175 \mathrm{c}$.

12. Мотов Ю.А. Петроглиф из урочища Ой-Джайляу // История и археология Семиречья. Алматы: ОФ «Родничок», 2011а. Вып. 4. С. 158-164.

13. Мотов Ю.А. Керамический тагарский сосуд из погребения в урочище ОйДжайляу // История и археология Семиречья. Алматы: ОФ «Родничок», 2011б. Вып. 4. С. 192-194.

14. Садуакасуль А., Железняков Б.А., Херманн Л. Наскальное искусство хребта Кулжабасы. Алматы: Жамбыл, 2017. 240 с.

15. Сала Р. Памятники Казахстана: Кулжабасы // Памятники наскального искусства Центральной Азии. Алматы: «Археологическая экспертиза», 2004. С. 6074.

16. Сала Р., Деом Ж-М. Пространственный анализ археологического комплекса Кульжабасы // Новые методы исследования в археологии: матер. междунар. науч.практ. конф., приуроч. 25-летию Независимости РК. Алматы: «Қазақ университеті», 2016. С. 55-72.

17. Свод памятников истории и культуры Жамбылской области. Кордайский район. Алматы: «Археологическая экспертиза», 2010. 396 с.

18. Свод памятников истории и культуры Жамбылской области. Чуйский район. Алматы: «Археологическая экспертиза», 2012. 368 с.

\section{Сведения об авторах:}

Горячев Александр Анатольевич - старший научный сотрудник, Институт археологии им. А.Х. Маргулана (г. Алматы, Казахстан); aga.2805@mail.ru

Потапов Станислав Александрович - научный сотрудник, Институт археологии им. А.Х. Маргулана (г. Алматы, Казахстан); potapov-stas@yandex.ru

Ильин Роман Владимирович - младший научный сотрудник, Институт археологии им. А.Х. Маргулана (г. Алматы, Казахстан); ilin-roman@mail.ru

\section{ХАНТАУ, АЙЫРТАУ ЖӘНЕ КІНДІКТАС ТАУЛАРЫНДАҒЫ ЕЖЕЛГІ ЕСКЕРТКІШТЕРГЕ ЖУРГІЗІЛГЕН АРХЕОЛОГИЯЛЫҚ БАРЛАУДЫН НӘТИЖЕЛЕРІ}

\section{А. А. Горячев, С. А. Потапов, Р. В. Ильин}

Мақалада Хантау, Айыртау және Кіндіктас тауларындағы ежелгі ескерткіштерге жүргізіген зерттеулер жүйеленді және қосымша археологиялық барлау жүргізілді. Алдын ала алынған мәліметтер аймақта ежелгі ескерткіштердің тығыз орналасқандығын көрсетуіне орай бірінші тәжірибелік зерттеу кезеңі космостық суреттер бойынша барлау жүргізу болды, одан кейін тікелей зерттеу болды. Алынған материалдарды камералдық өңдеу мен жүйелеу палеометал кезеңіндегі тұрғындардың шаруашылық - 
мәдени дәстүрін анықтау мақсатында жүргізілді. Зерттеу аймағы іргелес жазықтарды қосып алғанда ауданы 4000 шаршы км-ге жуық территорияны қамтыды. Топографиясы бойынша палеометал мен ерте темір дәуірінің 500-ге жуық, ал планиграфиясы бойынша 200-ге жуық ескерткіш материалдары жиналды. Ежелгі заманның 20-дан көп қоныс, 165 қорым және 17 петроглифтер шоғыры зерттелді. Кіндіктас тау-кен металургиялық орталығының палеометал кезеңінің 5 тау-кен қазбалары анықталды. Барлау нәтижесінде Хантау транзиттік коридорының батыс бөлегідегі ежелгі қоныс аударудың нақты бағыттарын анықтайтын мәліметтер алынды.

Түйін сөздер: археология, Жетісу, Орталық Қазақстан, транзиттік дәліз, палеометал кезеңі, археологиялық карта, қоныс, қорым, петроглифтер, тау-кен қазбалары, археологиялық кешен

\section{THE RESULTS OF ARCHAEOLOGICAL EXPLORATION OF ANCIENT MONUMENTS IN THE KHANTAU, AITAU AND KINDYKTAS MOUNTAINS}

\section{A. A. Goryachev, S. A. Potapov, R. V. Ilin}

In the framework of this project, researches of Ancient monuments were systematized and additional archaeological exploration was carried out in the mountains of Khantau, Aitau, Kuljabasy and Kindyktas. As preliminary data showed a dense saturation of the region with ancient monuments, the first stage of practical researches was their exploration by using satellite images with subsequent full-scale researches. Cameral processing and systematization of the obtained materials was carried out in order to clarify the economic and cultural traditions of the population of the region in the paleo metallic era.

Total area of the survey including adjacent valleys was about $4000 \mathrm{~km}^{2}$. There is collected topographic material of about 500 monuments of the paleo metallic era and the Early Iron Age, as well as the planigraphy of more than 200 of them. We have more than 20 settlements, 165 burial grounds and 17 clusters of petroglyphs of Ancient periods. There were revealed 5 mine workings of the paleo metal period in Kindyktas metallurgical center. Data to determine the specific routes of Ancient migrations in the Western part of the Khantau transit corridor has been the result of the exploration.

Keywords: archaeology, Jetysu, Central Kazakhstan, transit corridor, paleo metallic epoch, archaeological map, settlement, burial ground, petroglyphs, mine workings, archaeological complex

\section{REFERENCES}

1. Baipakov, K. M., Maryashev, A. N. 2004. Petroglify v gorah Kuljabasy (Petroglyphs in Kuljabasy mountains). Almaty: A.Kh. Margulan Institute of Archeology Publ. (in Russian).

2. Berdenov, S. A. 1998. In Samashev, Z. (ed.) Voprosy arheologii Kazahstana (Issues of archeology of Kazakhstan), 2. Almaty; Moscow: "Gylym” Publ., 180-190 (in Russian).

3. Voyakin, D. A., Goryachev, A. A., Ilin, R. V., Duysebayeva, T. N. 2019. In 11Orazbaev chteniya (11-Orazbaev reading). Almaty: "Kazakh University” Publ., 126-132 (in Russian).

4. Goryachev, A. A., Ilin, R. V. 2019. In Metody i metodologiya estestvennyh nauk v polevyh arheologicheskih issledovaniyah (Methods and methodology of natural Sciences in field archaeological research). Almaty: "Kazakh University" Publ., 150-164 (in Russian).

5. Krasnov, A. N. 1888. In Izvestiya Russkogo geograficheskogo obshchestva (Proceedings of the Russian Geographical Society), 23, 436-481 (in Russian).

6. Maryashev, A. N., Goryachev, A. A. 1992. In Arheologicheskie issledovaniya v Kazahstane (Archaeological researches in Kazakhstan). Alma-Ata: Abay Kazakh Pedagogical Institute Publ., 3-15 (in Russian). 
7. Maryashev, A. N., Goryachev, A. A. 1993. In Rossiyskaya arheologiya (Russian archeology), 1, 5-19 (in Russian).

8. Maryashev, A. N., Goryachev, A. A. 2002. Naskalnye izobrazheniya Semirechiya (Rock images of Semirechiye). Almaty: "Fond «XXI vek»" Publ. (in Russian).

9. Maryashev, A. N., Goryachev, A. A. 2008. In Izvestiya NAN RK. Seriya obshchestv. nauk (News of NAS RK. Social Sciences Series), 1 (254), 101-109 (in Russian).

10. Maryashev, A. N., Zheleznyakov, B. A. 2013. Drevnosti Kulzhabasy (Antiquities of Kuljabasy). Almaty: A.Kh. Margulan Institute of Archeology Publ. (in Russian).

11. Medoev, A. G. 1979. Gravyury na skalah. Sary-Arka, Mangyshlak (Engravings on the rocks). Alma-Ata: "Jalyn” Publ. (in Russian).

12. Motov, Yu. A. 2011a. In Istoriya i arheologiya Semirechiya (History and archaeology of Semrechie), 4. Almaty: “OF «Rodnichok»” Publ., 158-164 (in Russian).

13. Motov, Yu. A. 2011b. In Istoriya i arheologiya Semirechiya (History and archaeology of Semrechie), 4. Almaty: "OF «Rodnichok»” Publ., 192-194 (in Russian).

14. Saduakasuly, A., Zheleznyakov, B. A., Hermann, L. 2017. Naskalnoe iskusstvo hrebta Kulzhabasy (Rock art of Kuljabasy ridge). Almaty: "Zhambyl” Publ. (in Russian).

15. Sala, R. 2004. In Pamyatniki naskalnogo iskusstva Tsentralnoy Azii (Monuments of rock art in Central Asia). Almaty: "Arheologicheskaya ekspertiza” Publ, 60-74 (in Russian).

16. Sala, R., Deom, Zh.-M. 2016. In Novye metody issledovaniya v arheologii (New researches in archaeology). Almaty: "Kazakh University" Publ., 55-72 (in Russian).

17. Svod pamyatnikov istorii i kul 'tury Jambylskoy oblasti. Kordayskiy rayon (Arch of historical and cultural monuments of Jambyl region. Korday ditrict). 2010. Almaty: "Arheologicheskaya ekspertiza" Publ. (in Russian).

18. Svod pamyatnikov istorii i kul 'tury Jambylskoy oblasti. Chuyskiy rayon (Arch of historical and cultural monuments of Jambyl region. Chu ditrict). Almaty: "Arheologicheskaya ekspertiza" Publ. (in Russian).

\section{About the Authors:}

Goryachev Alexander A. Senior scientific researcher, A.Kh. Margulan Archeology Institute, Almaty, Kazakhstan; aga.2805@mail.ru

Potapov Stanislav A. Scientific researcher, A.Kh. Margulan Archeology Institute, Almaty, Kazakhstan; potapov-stas@yandex.ru

Ilyin Roman V. Junior scientific researcher, A.Kh. Margulan Archeology Institute, Almaty, Kazakhstan; ilin-roman@mail.ru

\footnotetext{
Мүдделер қақтығысы туралы ақпаратты ашу. Авторлар мүдделер қақтығысының жоқтығын мәлімдейді. / Раскрытие информации о конфликте интересов. Авторы заявляют об отсутствии конфликта интересов. / Disclosure of conflict of interest information. The authors claims no conflict of interest.

Мақала туралы ақпарат / Информация о статье / Information about the article. Редакцияға түсті / Поступила в редакцию / Entered the editorial office: 18.12.2019.

Рецензенттер мақұлдаған / Одобрено рецензентами / Approved by reviewers: 25.12.2019. Жариялауға қабылданды / Принята к публикации / Accepted for publication: 08.01.2020.
} 